\title{
Streamlining Government Financing Programs for SMEs in the Sub-Saharan Africa: The Case of Botswana
}

\author{
Mengsteab Tesfayohannes \\ Susquehanna University, PA, USA
}

\begin{abstract}
The issue of SMEs financing is complex and we should address it on a priority basis. Although SMEs should be motivated to initiate their own means of solving their financing problems, their capacity is limited and the role of other stakeholders in the financial sector is vital. In this scenario, governments have a major role to play. Strengthening the government's role is very important since it acts as a catalyst, investor and regulator to strengthen the supply-side of the economy. This paper discusses what role the Government of Botswana (GoB) can effectively play in facilitating SMEs financing. The author proposes four financing packages containing schemes for possible use by the $\mathrm{GoB}$ - direct financial assistance schemes; loan guarantee schemes; direct credit grant schemes; and financing of technical and managerial advisory services. Stakeholders need to evaluate these schemes from the economic rationality point of view before they are opted for implementation.
\end{abstract}

Keyterms: small, medium and micro enterprises, financing, government financing schemes, financing institutions

\section{Introduction}

Small, medium and micro enterprises (SMEs) are widely regarded as the engine of economic growth in both developing and developed nations (Tesfayohannes, 1998). They are substantial generators of local and broad-based employment; promoters of indigenous entrepreneurship and innovation; and providers of goods and services to the local population and beyond. Nations in the sub-Saharan Africa (SSA) already recognized the vital role of SMEs, and they are keen to give priority for their development (Briscoe, 1995). However, SMEs require a nurturing environment and supporting infrastructure for sustainable development. There are vital external and internal factors affecting SMEs' development in any national socio-economic framework. The external ones are national institutional capacity, regulatory framework, training and entrepreneurial development, access to finance, market opportunities, technological support and suitable socio-cultural and political environment (Liedholm, 1993; Rodinelli \& Dasarda, 1992; Tesfayohannes, 1998). Although all the above factors require consideration, lack of finance has continued to be the major concern and the main cause for untimely failure of many SMEs (Liedholm, 1993; Morewagae, Monica, \& Henry, 1995). This is particularly a common phenomenon for SMEs in the developing countries (National Small Business Regulatory Review, 1999). SMEs'

Mengsteab Tesfayohannes, Ph.D., Associate Professor of Management, Sigmund Weis School of Business, Susquehanna University.

Correspondence concerning this article should be addressed to Mengsteab Tesfayohannes, Sigmund Weis School of Business, Susquehanna University, PA, USA. E-mail: tesfayohannes@susqu.edu. 
financing is complex and all stakeholders need to address the issue skillfully and prudently. There are numerous potential sources of financing for SMEs. We can broadly categorize them as: equity financing, debt financing, special purpose and governmental sponsored financing (Tesfayohannes, 1998). These categories have their own distinctive methods of dealing with the qualified SMEs. But, an effective partnership between financial institutions, cooperative funds, the government, private and cooperative investors, venture capital firms, investment angels, and non-bank financial institutions can ideally facilitate SMEs' access to finance.

Botswana is a middle-income country located in Sothern Africa. It is a peaceful, democratic nation with a striving national economy. The country has an effective private sector led sustainable economic development agenda that promotes gender aware economic diversification, poverty reduction and SMEs' development (National Development Plan 8, 1998; Vision, 2016, 1996). In line with its core development agenda, the Government of Botswana (GoB) issued a special policy on SMEs development (National Policy on SMEs, 1999). During the last 10 years, the GoB through its responsible institutional capacities attempted to implement those policy directives, modalities and strategic objectives with the support of other community-based stakeholders. So far, results are not as desired and local SMEs have continued to suffer from lack of access to finance (Task Force Report, 1998).

In this paper, the author focuses on how governments can play a catalyst role as investor and regulator of the financial environment with the desired effectiveness. Moreover, the author discusses the Whys and Hows of the direct and indirect roles of the GoB towards alleviating SMEs financing problems. Although, the author doesn't believe that governments can solve SMEs' financing problems totally, they can substantially facilitate SMEs' access to finance. This is particularly true in the case of nations in SSA. In the author's opinion, governments in SSA are currently overstretched due to their excessive involvement in many vital responsibilities and regulatory attributes. The aim here is to recommend feasible government sponsored SMEs' financing schemes that GoB can initiate, handle and implement through its appropriate institutions and agencies. This can be a small contribution towards the efforts to achieve the desired goal and strengthen the effectiveness of SMEs financing scenario in Botswana. The GoB is keenly interested in actively promoting SMEs as the engines of economic growth and social prosperity. SMEs access to finance is an important issue, and the GoB's role is cardinal. The author believes that the financing schemes the author conceptually proposes in this paper can also be useful for other SSA nations facing similar problems.

\section{SMEs as the Engine of Growth}

Unfortunately, some policy makers still regard SMEs as the consequences of the failure to apply the conventional economic development paradigms exclusively stated in the Neo-classical School of Economic Thought. This comprehensive grasp on SMEs has given the impetus for the attitude of viewing them as lonely entities with immutable diseconomies (Kuratko \& Hodgetts, 2007). However, all major entrepreneurial innovations and killer applications (groundbreaking innovations) that have been responsible for drastic changes in our economic and social life were largely the result of SMEs' innovative activities and related entrepreneurial attributes (Kuratko \& Hodgetts, 2007). However, currently SMEs are high in the developmental agendas of all nations as important contributors to national economies (Hull, 1983; McPherson, 1996). More than any time, African nations have now embraced the paramount importance of SMEs as a vital motive force of innovation, 
change, and development (Owualah, 1988; Liedholm \& Fuzzy; 1994; McGrath \& King, 1999, Van Dijk \& Sandee, 2002). Beyond the narrower spectrum, African nations should comprehend that the key to economic growth in any country lies in creating the necessary infrastructures that support the promotion of SMEs (Roux, 1999). This mandatory prerequisite can potentially help to overcome constraints hindering the enhanced developmental scope of SMEs (McCormick, 1999).

As briefly mentioned earlier, the current position of SMEs in Botswana is not rosy. At least at this time, they are not contributing to the national economy in line with their expectations. In fact, they are currently plagued with technical, regulatory, organizational, financial and other institutionally related problems at both macro- and micro-levels (Hinton, Mokobi, \& Sprokel, 2006). Even with all their formidable challenges, they are still significant to Botswana's economy (Briscoe, 1985; Daniels \& Fisseha, 1992; Cuncombe \& Heeks, 2001). They continued to actively participate in all vital sectors of the national economy (Sunny, 2000). Unfortunately, Botswana has only rudimentary statistical data and it is difficult to have a full knowledge on the structure of SMEs' and their contribution to GDP and broad employment. However, according to the Presidential Taskforce Report (1998) and Botswana aggregate Statistical Report, 2007/2008, SMEs annually contribute approximately 25-35 percent of the country's GDP. Their contribution to employment is more appreciable and accounts for 50 percent of the total formal employment. This is indeed an indication that Botswana is working effectively for the full-fledged development of SMEs' as vital economic motive forces that serve as a means of providing equitable benefits for the majority (Curry, 1987). In line with the strategic agenda, SMEs occupied a center stage in government's endeavor to achieve sustainable industrial development (Sunny, 2000). As articulated in the SME national policy, the current GoB efforts focused on: employment creation, poverty alleviation, economic diversity promotion, indigenous entrepreneurship advancement and fostering successful economic competition. This is in line with the country's long-term vision towards advancement and prosperity for all (Vision, 2016, 1996). GoB should also continue to create an enabling environment for collaboration and partnership with other stakeholders for the speedy realization of the desired strategic objectives.

\section{Some Fundamental Aspects of SMEs’ Financing}

\section{The Financing Constraints}

Some have argued that SMEs do not need special financing schemes and they should compete in the financial market (Mazumdar, 1989). However, many studies have advocated for SMEs' focused financing as they suffer most due to lack of suitable access to finance. This lack of finance is the toughest constraint in most of the developing nations (Cook, 2001; Lycette \& White, 1989; Harrison \& McMillan, 2003; Kurwijila \& Due, 1991). For example, Levy (1993) emphasized in his study that the lack of finance is the primary bottleneck to smaller business operation expansion in the leather and furniture industries in Sri Lanka and Tanzania. In a similar way, studies conducted in other African nations like Ghana, Kenya, Nigeria, Ethiopia, and South Africa have shown that the major cause of small enterprises' failure is their inability to obtain adequate financing (Schoombe, 2000; Bigsten et al., 2000; Aryeetey, 1993; Oyejide, 1993; Marana, 1993; Demesne, 1993). In their study, Morewagae et al. (1995) found that the ability of SMEs to obtain funds is constrained by the lack of information, complicated application procedures, high collateral or security requirements, high interest rates, and harsh repayment terms. To a lesser degree, this case is also felt in the developed countries (Brigham, 1983; Harrison \& Mason, 1993). 
Walker and Petty (1986) noted that SMEs are subject to greater business and financial risks and are more vulnerable to bad decisions than their larger counterparts. SME financing problems stem from the lack of capacity to obtain funds at the right time, of the right type, in the desired amount and at various stages of development (Bates \& Hally, 1982). Many potentially innovative and productive entrepreneurs in SSA have failed because of a lack of finance (Tesfayohannes, 1998).

Numerous studies identified several case specific and general problems related to SMEs' financing problems (Task Force Report, 1998; Liedholm, 1993; Rempel et al., 1994; Morewagea et al., 1995; Lisenda, 1997). The common problems that affect SMEs in SSA nations are: conservative approach of the financial industry; less effective governmental regulatory frameworks; internal organizational and financial weakness of the SMEs; less recognition of the role of SMEs as the engine of economic growth; in-adequate entrepreneurial and managerial acumen of SMEs' owners and managers; the marginal role and availability of informal financing sources in the society; and the non-supportive role of institutions and agencies representing the interests of SMEs (for example: Chambers of Industry and Commerce, Entrepreneurs Association, Financial Cooperatives and other concerned agencies representing the SMEs sector).

\section{SMEs Financing in Botswana}

In Botswana, entrepreneurs, particularly the local ones, have continued to complain about the limited access to finance. Their complaints emanated from the conservative attitude of banks and other commercial lenders towards SMEs loan requests (for example, lack of the required information, complicated application procedures, high collateral or security requirements, high interest rates, and imposing harsh loan repayment terms). The GoB established and assigned a high-powered Task Force in 1997 to conduct an in-depth study on the general situation of SMEs in the country. The objective was to respond to the continued complaints and dissatisfaction of SMEs owners about access to finance and other problems related to SMEs in the country. The task force produced a comprehensive Presidential Task Force Report (Task Force Report, 1998). The report contained new and extended promotional approaches and recommendations targeting: the Institutional and Regulatory Framework; Education, Training and Entrepreneurship Development; Access to Finance; and Support for Marketing and Technological Development.

According to the report, the current sources of finance for SMEs in Botswana are: personal and other related sources; government financial assistance mainly through Financial Assistance Policy (FAP); loans from commercial banks; loans from National Development Bank; and loans from other financial institutions. The task force report revealed that personal savings and contributions from family or friends and other unknown informal and semi-formal sources (informal lenders) account for more than 70\% of SMEs financing. This shows that the majority of SMEs in Botswana have relatively few opportunities to obtain finance from sources other than the above mentioned non-commercial sources. These limitations continued to have negative impact on SMEs. This phenomenon in turn significantly discouraged other potential entrepreneurs from involvement in establishing entrepreneurial ventures.

The report further indicated that commercial banks are formally ready to provide loans up to Pula $100,000^{1}$ to SMEs. However, entrepreneurs frequently criticize commercial banks for their hesitation and excessive

\footnotetext{
${ }^{1}$ Pula is the name of Botswana Currency (legal tender) and the current exchange rate is: 6 Pula is equivalent to one US Dollar.
} 
conservatism in dealing with lending to SMEs by imposing excessive bureaucracy. Commercial banks complained about the unreliability of SMEs due to lack of collateral, insufficient equity contribution of owners, inadequate financial record and poorly prepared business plans and are hesitant to extend loans to SMEs. It can be concluded that the current commercial banks' role to alleviate SMEs financing problems has proven to be limited and discouraging. It is in fact accounting for only two percent of the required finance at both start-up and post-start-up stages (Lisenda, 1997). This is unacceptable by any yardstick.

The GoB also facilitated alternative sources of finance for SMEs mainly from the government-owned development banks and special funding agencies in the country. The existing institutions of this kind are: The National Development Bank (NDB), Tswelelo and the Botswana Development Corporation (BDC). Surprisingly, NDB lending policies and regulations are more or less similar to the commercial banks. Its minimum loan is Pula 20,000. This amount is far less than the minimum loan provided by the commercial banks. Tswelelo is no longer functional due to sustained losses emanated from its very poor lending and loan collection processes. The minimum BDC's loan provision is Pula 200,000. This automatically targets bigger enterprises with higher needs for finance. There are some other nominal financing agencies like Women's Finance House Botswana (WFHB), Cooperation for Research, Development and Education (CORDE) and Rural Industries Innovation Center. These Non-governmental Organizations (NGOs) mostly limited to a narrower domain. Their objective is just to provide small supplementary loans and financial assistance to cover some of the ad hoc financing needs of SMEs.

The Financial Assistance Program (FAP) was launched by the GoB to provide financial assistance and loan grants to qualified SMEs owned by local entrepreneurs. The objective was to foster grass roots level self-employment and provide more opportunity for the qualified Botswana citizen entrepreneurs to grow further and register success. The GoB introduced FAP in 1982 and amended it in 1995. Compared to other programs, FAP was well organized and intended for a wider coverage. FAP's maximum financial assistance in term of loan was Pula 75,000 with strict criteria. For example, to qualify for FAP financing the applicant must be a Botswana citizen, aged 18 years or older and should fulfill many other qualifying criteria. The maximum FAB financing is to cover up to $90 \%$ of the required investment of the qualified projects. FAP funds gave priority to projects located in rural areas and those venture projects owned by women. The intention was good, but FAP was not successful in meeting its strategic objectives. According to the task force report (1998), only 4\% of SMEs got assistance from FAP. This well intentioned scheme suffered from extensive mismanagement, nepotism, corruption and inefficiency. In fact, it played a nominal role in creating sustainable, innovative and viable business ventures in the country. The GoB terminated the program and created the Citizens' Entrepreneurial Assistance Policy (CEDA) in 2001 (Analytics, 2003). This new agency should continue to dedicate itself to surmount the challenge of initiating government sponsored SME financing schemes based on fulfilling strict and viable requirements. CEDA has also continued to suffer from multiple problems, and its ability to provide adequate services to its clients has continued to suffer as well (Hinton et al., 2006).

The above briefly expressed impediments have played their own role in aggravating the situation. To alleviate these and other problems, the task force gave some comprehensive SMEs financing recommendations. They include the following: lending and credit-guarantees; setting-up mechanisms for improving the capacity of SMEs to access finance; and improving the effectiveness of the financial assistance and lending programs still 
currently active. Unfortunately, the task force recommendations are very general and lack specific application modalities and technical and action plan preparations. Successful application in turn demands the design of specific, viable and target-oriented financing schemes. Unlike other governments in SSA, the GoB has a strong financial capacity due to substantial revenue from diamond and other precious mineral exports (Morewagae et al., 1995; Analytics, 2003). This means the GoB has the ability to help SMEs at least to ease their financing problems in a viable way. However, this does not mean that government should solve every SMEs financing problems. In both developed and developing nations, what governments can do is limited. Governments have many other socio-economic related commitments (Chunyun, 2003). However, government support can play a crucial role in the survival and growth of SMEs. This should include helping them to alleviate their financing problems by launching certain target-oriented and wider outreached financing schemes (Chase et al., 1983; Deutsche Ausgleich Bank-DtA, 1996). In line with this assertion, the author formulated some financing schemes that might help GoB policy makers and stakeholders in charge of promoting SMEs in the country. The proposed schemes are not ready-made and are just for brain storming. Stakeholders need to appraise and substantiate them from their opportunity cost point of view.

\section{Recommended Government Sponsored SMEs’ Financing Schemes}

As briefly discussed above, GoB indeed participated in promoting SMEs' financing initiatives through various schemes and programs. All these initiatives are relevant and supportive, but they should be implemented in the best possible way to improve SMEs financing outreach. This means GoB should search for better and more innovative ways of implementing established initiatives as part of its continuous improvement endeavors. Effective implementation requires the capability to streamline, cluster, and properly manage SMEs financing initiatives. The first action is clustering the existing fragmented government sponsored SMEs financing schemes and action programs into SMEs financing packages. Well packaged, organized and clustered schemes and action programs can be easier to implement and offer better management of financing outreach activities. The author therefore proposed seven packages each of which can contain several government sponsored SMEs' financing schemes (see Figure 1). From the seven packages comprehensively proposed, the author selected the following four packages: Direct Financial Assistance Schemes; Loan Guarantee Schemes; Direct Credit Grant Schemes; and Financing of Technical and Managerial Advisory Services. The author would like to emphasize that it is easy to design and propose schemes and action programs, but the most difficult task is to successfully implement and broaden the outreach to the targeted beneficiaries. This challenge rests mainly on the shoulders of the executing agencies. A systematic approach for the design and implementation of government sponsored SMEs' financing schemes is shown in Figure 2. Each one of the SMEs' financing packages proposed in Figure 1 should act as an umbrella for the proposed SMEs financing schemes and action programs related to each of them.

\section{Direct Financial Assistance Schemes}

As mentioned earlier, national governments in the developing economies control and own a large portion of national wealth and endowments including vital financial institutions like commercial banks. This provides the ability and strength to launch a variety of government sponsored initiatives and action programs including 
providing direct financial support for qualified SMEs. In the same way, the GoB can launch time bounded direct financial assistance schemes to provide non-obligatory funds to qualified SMEs as a contribution to their sustainable development. In line with its commitment, the GoB has already established specialized agencies like Citizens’ Entrepreneurial Development Agency (CEDA) and Small Business Promotion Agency (SBPA) to provide its support through these types of agencies if they continue to function effectively by launching direct financial assistance related schemes and action programs. Table 1 shows the author's recommendation in this package. The proposed schemes are general in their contents and intended just for brain storming purpose and adaptation. GoB can also design and launch numerous other schemes under the same umbrella (package). The author needs to emphasize that these and other related schemes should undergo through direct or indirect critical evaluation in the light of their contribution to meeting the anticipated goals in the given environment.

\section{Bank Loan Cost Subsidization and Loan Guarantee Programs}

Banks and other formal lenders assume that the cost of processing loan applications submitted by SMEs is excessive. This may be one of the main reasons for their reluctance to grant loans to SMEs. Unfortunately, the majority of commercial banks uniformly consider SMEs as borrowers with unstable credit worthiness and most vulnerable to the risk of default. Therefore, banks usually expect to bear a burden and incur extra costs in dealing with lending to SMEs. Especially if there are central bank imposed interest rate ceilings that do not reflect the actual market, commercial banks assume that lending to SMEs is not affordable. In this situation, government risk sharing programs can motivate banks to lend and provide professional help to SMEs. Concerned GoB agencies can initiate appropriate risk sharing action schemes pertaining to loan cost subsidization and loan guarantee. They should ensure that the designed programs effectively assist qualified banks and other lenders to enable them to serve the needy SMEs as desired. Government subsidies and loan guarantees can help a great deal in building the commercial financial institutions' confidence and motivation to participate in alleviating SMEs' financing problems. Just for brain storming, the author proposed some potentially feasible government sponsored bank loan cost subsidization and loan guarantee schemes as shown in Table 2.

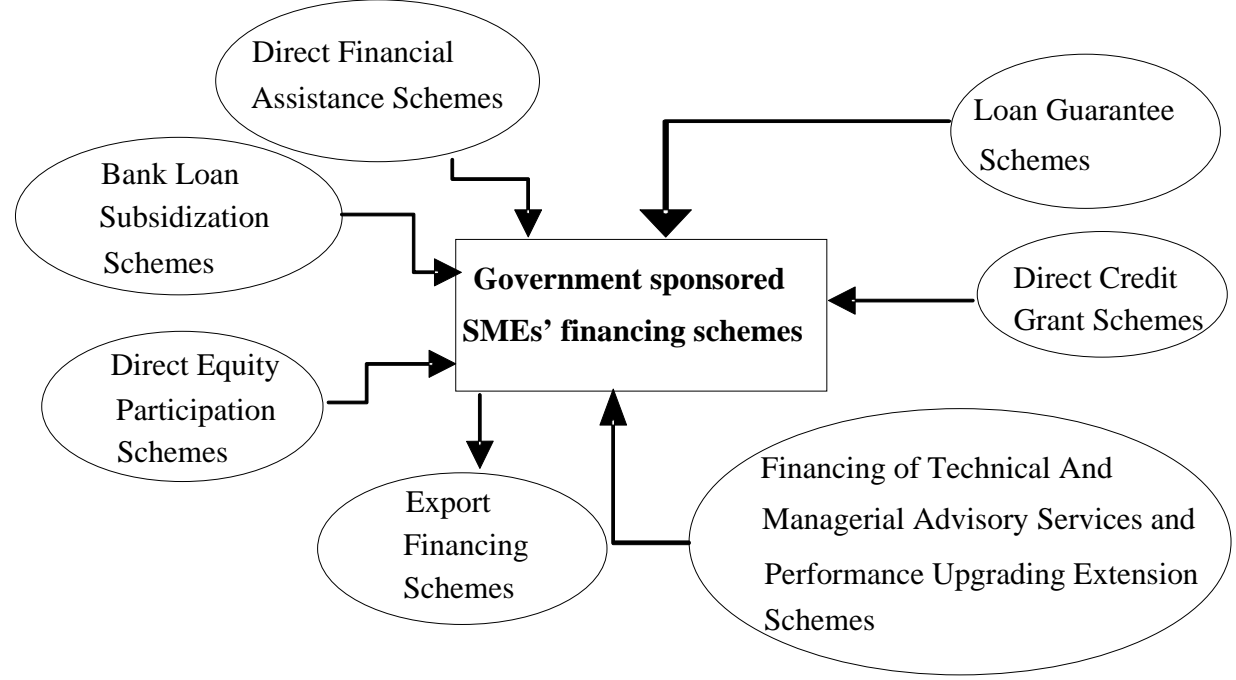

Figure 1. Recommended government sponsored SMEs’ financing schemes in Botswana. 


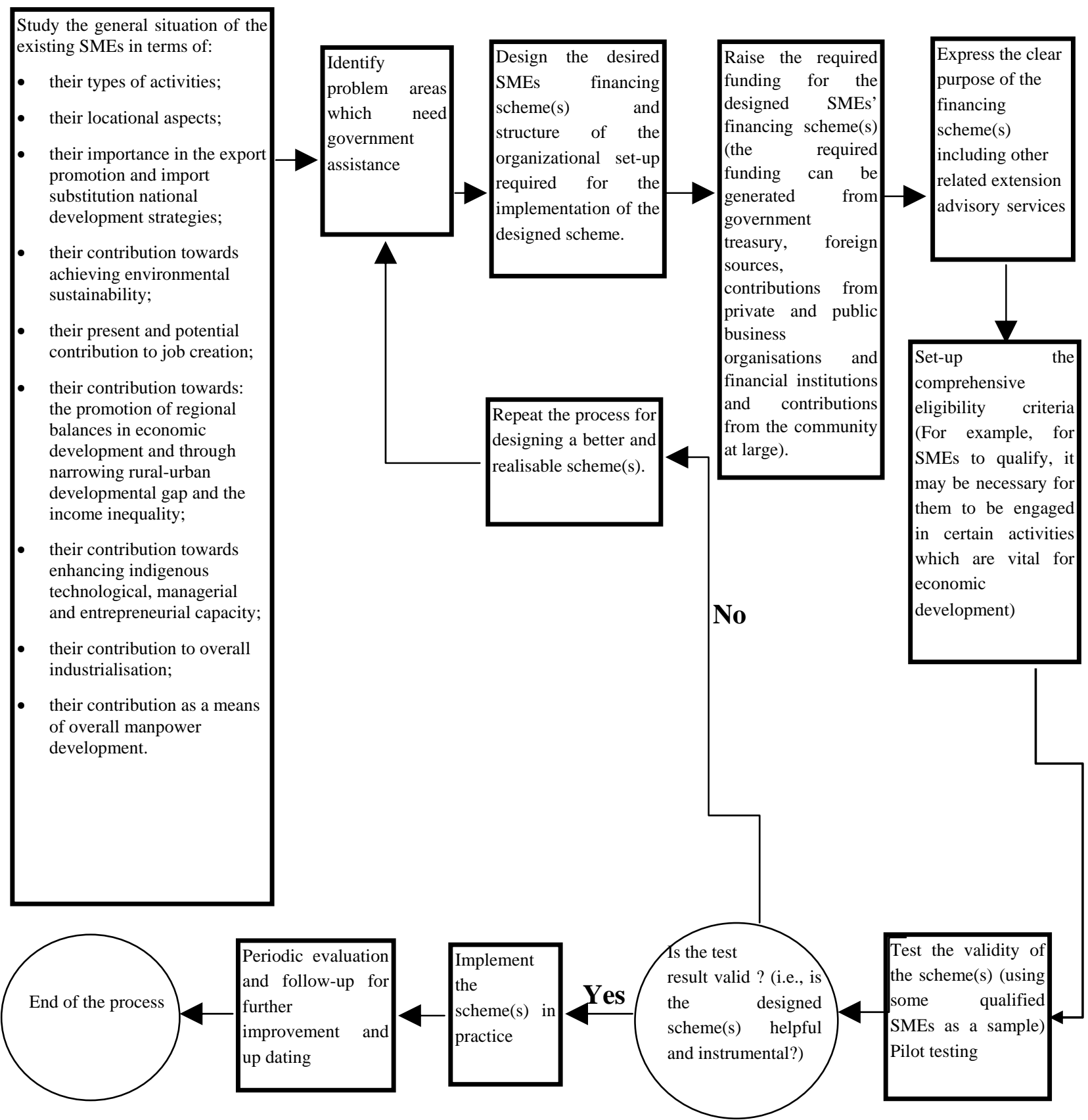

Figure 2. Methodological steps of government sponsored SMEs’ financing schemes.

Table 1

Proposed Government Direct Financing Schemes for SMEs in Botswana

\begin{tabular}{|c|c|c|c|}
\hline Scheme & Objective & Targeted beneficiaries (eligibility) & Possible sources of funding \\
\hline $\begin{array}{lr}\text { Industrial } & \text { Feasibility } \\
\text { Study } & \text { Cost } \\
\text { Coverage } & \text { Financial } \\
\text { Grant } & \end{array}$ & $\begin{array}{l}\text { To finance feasibility studies } \\
\text { for new ventures or for } \\
\text { expansion projects } \\
\text { established firms }\end{array}$ & $\begin{array}{l}\text { SMEs at their seed (foundational) } \\
\text { stage } \\
\text { SMEs with a concrete expansion } \\
\text { project especially in a government } \\
\text { declared target zones or sites }\end{array}$ & $\begin{array}{l}\text { Government treasury } \\
\text { Foreign donations } \\
\text { Contributions from the business } \\
\text { community through their representative } \\
\text { agencies (organizations) }\end{array}$ \\
\hline
\end{tabular}


(Table 1 continued)

\begin{tabular}{|c|c|c|c|}
\hline Scheme & Objective & Targeted beneficiaries (eligibility) & Possible sources of funding \\
\hline $\begin{array}{l} \\
\text { Special Industrial } \\
\text { Promotional Zone } \\
\text { Development } \\
\text { Grants }^{2}\end{array}$ & 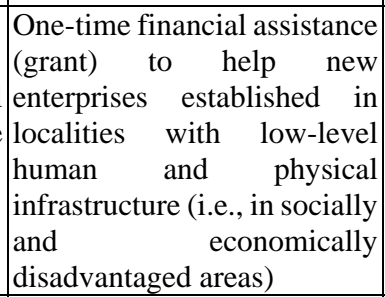 & $\begin{array}{l}\text { For newly established SMEs in } \\
\text { areas relatively underdeveloped } \\
\text { but designated as target locations } \\
\text { for development }\end{array}$ & $\begin{array}{l}\text { Government treasury } \\
\text { Community groups of the Targeted areas } \\
\text { Contributions from the business } \\
\text { community in the targeted location }\end{array}$ \\
\hline $\begin{array}{ll}\text { Research } & \text { and } \\
\text { Innovation } & \\
\text { Development } & \text { Grant } \\
\text { (Fund) } & \end{array}$ & $\begin{array}{l}\text { To finance partially or fully } \\
\text { the technological r and } \\
\text { innovation } \quad \text { works r and } \\
\text { discoveries conducted by } \\
\text { SMEs. }\end{array}$ & $\begin{array}{l}\text { SMEs that can convincingly } \\
\text { demonstrate their innovative } \\
\text { results (new products) will have } \\
\text { practical and purposeful use for the } \\
\text { society and a significant market } \\
\text { potential in both local and foreign } \\
\text { markets }\end{array}$ & $\begin{array}{l}\text { Government treasury } \\
\text { Other concerned private and foreign } \\
\text { agencies (GOs, NGOs and international } \\
\text { organizations) can make supplementary } \\
\text { financial contributions }\end{array}$ \\
\hline $\begin{array}{l}\text { Energy Problems } \\
\text { Alleviation Fund }\end{array}$ & $\begin{array}{l}\text { To encourage SMEs to } \\
\text { alleviate their energy supply } \\
\text { problems and through that } \\
\text { promote industrial efficiency }\end{array}$ & $\begin{array}{l}\text { SMEs located in areas with } \\
\text { insufficient energy supply }{ }^{3} \text {. SMEs } \\
\text { engaged in manufacturing of } \\
\text { exportable goods may get priority }\end{array}$ & Government treasury \\
\hline
\end{tabular}

Table 2

Recommended Government Sponsored Bank Loan Cost Subsidization and Loan Guarantee Schemes

\begin{tabular}{|c|c|c|c|}
\hline Scheme & Objective & beneficiaries & Possible sources of funding \\
\hline $\begin{array}{l}\text { Loan } \\
\text { Subsidization } \\
\text { Scheme }\end{array}$ & $\begin{array}{l}\text { To cover partly or fully } \\
\text { the extra cost incurred by } \\
\text { banks because of their } \\
\text { lending (financing) to } \\
\text { SMEs }\end{array}$ & $\begin{array}{l}\text { SMEs located in rural and } \\
\text { semi-urban areas and principally } \\
\text { use locally produced inputs for } \\
\text { their production activities }\end{array}$ & $\begin{array}{l}\text { Government treasury } \\
\text { Levy from profits of large companies and the } \\
\text { SMEs' through their representative agencies } \\
\text { Contributions made by banks }\end{array}$ \\
\hline $\begin{array}{l}\text { SMEs Start-up Loan } \\
\text { Guarantee Scheme }\end{array}$ & $\begin{array}{l}\text { To provide wider } \\
\text { financing accessibility } \\
\text { for SMEs at their start-up } \\
\text { stages }\end{array}$ & $\begin{array}{|lrr|}\text { SMEs at their start-up stage, } \\
\text { emphasizing their managerial, } \\
\text { technical } & \text { and } r \text { other } \\
\text { developmental } & \text { policies related } \\
\text { requirements } & & \\
\end{array}$ & $\begin{array}{l}\text { Government treasury, } \\
\text { Contributions from banks } \\
\text { Foreign donors } \\
\text { Contributions from the existing both SMEs and } \\
\text { large-scale firms }\end{array}$ \\
\hline $\begin{array}{l}\text { Guarantee Fund for } \\
\text { Women } \\
\text { Entrepreneurs }\end{array}$ & $\begin{array}{l}\text { To provide guarantee to } \\
\text { financial institutions } \\
\text { intend to lend to SMEs } \\
\text { owned by women for the } \\
\text { purpose of covering } \\
\text { working capital and } \\
\text { investment needs }\end{array}$ & 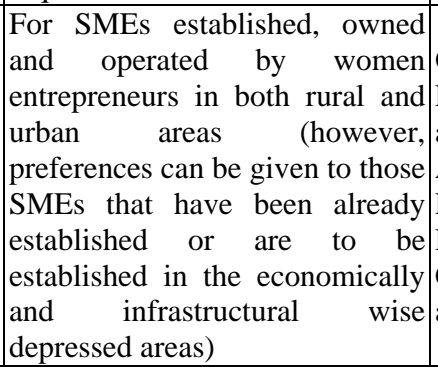 & $\begin{array}{l}\text { Government treasury } \\
\text { Foreign and domestic donor agencies and } \\
\text { associations (like the National Women's } \\
\text { Association) } \\
\text { Private sector } \\
\text { Representative organizations (like Chamber of } \\
\text { Commerce Industry, and other entrepreneurial } \\
\text { and professional associations) }\end{array}$ \\
\hline $\begin{array}{l}\text { Special loan } \\
\text { Guarantee Scheme }\end{array}$ & $\begin{array}{l}\text { To increase the } \\
\text { availability of funding } \\
\text { (loan) for the purpose of } \\
\text { start-up, expansion, and } \\
\text { modernization of SMEs }\end{array}$ & \begin{tabular}{|l} 
For SMEs established by \\
disadvantaged and promising \\
citizens
\end{tabular} & $\begin{array}{l}\text { Government treasury } \\
\text { Local community at large contributions } \\
\text { Bilateral and multilateral donations } \\
\text { Contributions from profits of financial } \\
\text { institutions and other private, parastatal and } \\
\text { fully state owned business organizations } \\
\text { (corporations) }\end{array}$ \\
\hline
\end{tabular}

\footnotetext{
${ }^{2}$ In line with the rationalised development strategy of the country, the objective of this proposed incentive scheme is to motivate entrepreneurs to establish SMEs in "Economically and Socially Depressed Areas".

${ }^{3}$ In remote parts of Botswana where there are shortages of energy supply (particularly electricity), SMEs located there can have their own electricity generators. In this respect, government can make fixed time partial financial contributions to cover the cost of generators, and to subsidise cost of petrol like diesel needed to run generators possessed by the SMEs.
} 
The aim of the above-proposed loan guarantee schemes is to cover in case a borrower defaults. Both the government and the lender can share losses, due to defaults, proportionally. Customarily, loan guarantee schemes usually cover 50\% to 95\% of the losses incurred from defaulting SMEs (OECD Comprehensive Report, 1995). The success of these types of schemes depends at least on the following general characteristics:

- They should be flexible and responsive to the changing needs and situations of borrowers, lenders, and the national economy;

- They should be appropriate, implementable and less bureaucratic. Potential beneficiaries should be able to benefit from them in the most feasible way;

- They have to be properly designed and efficiently administered in keeping with the spirit of the given legislation;

- They have to be in line with the formulated objectives, eligibility preconditions and working systems as a prerequisite for their success;

- They should have adequate budget necessary for fulfilling their mandated operation goals;

- They have to be effective, efficient and innovative in order to attract and convince client financial institutions to participate in the program and enhance their participation in financing SMEs;

- They should promote prudent responsibility on the part of borrowers and lender institutions.

In general, loan guarantee schemes should achieve financial autonomy without losing their main purposes. The main concern is how to implement the designed schemes related to the program. To streamline the implementation process, the schematic flow chart in Figure 3 might help. The author designed this assuming that it might facilitate the challenging task of implementation. In Botswana, CEDA and SBPA are in the best position to participate in the implementation of loan cost subsidization and guarantee programs.

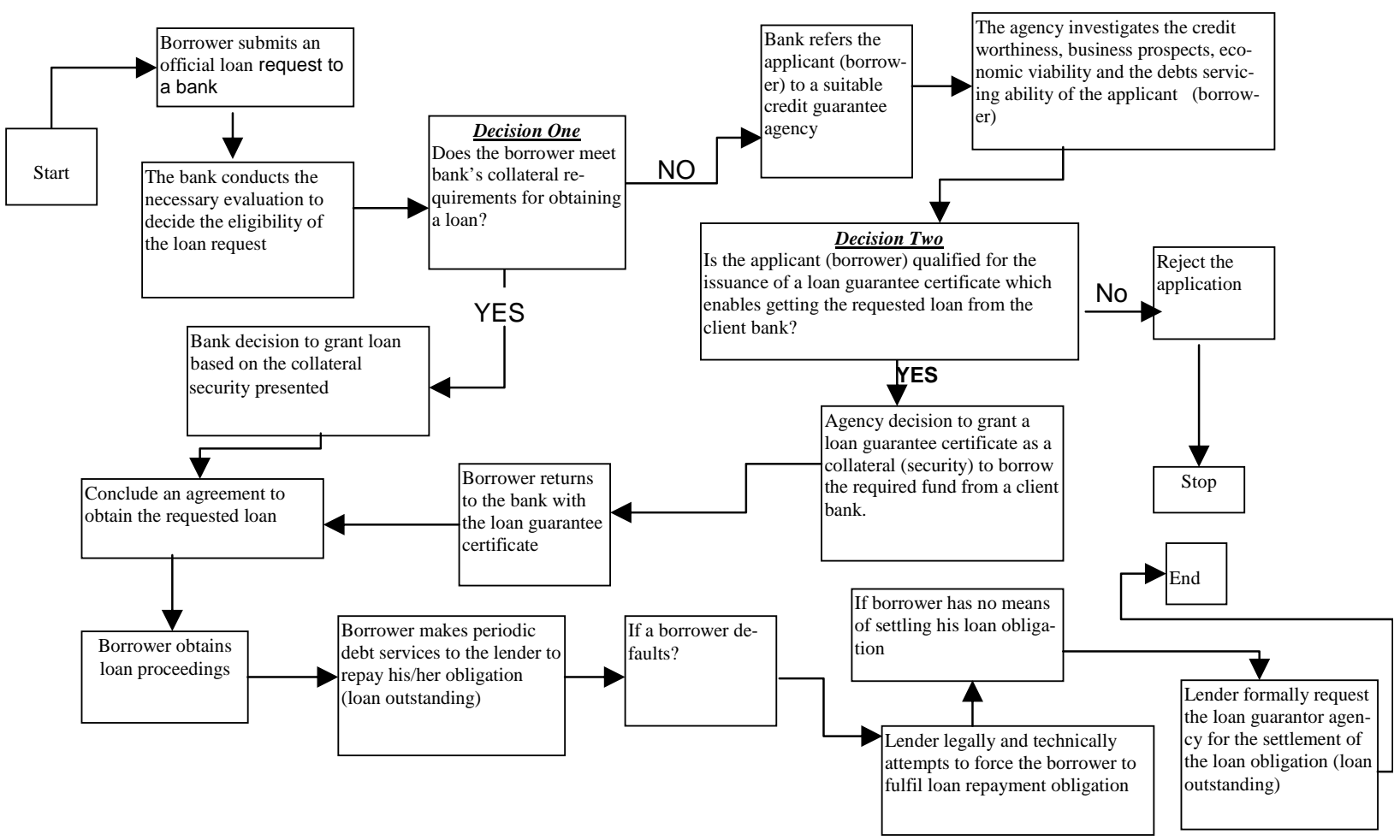

Figure 3. Schematic flow of implementation process of a loan guarantee scheme for SMEs debt financing. 


\section{Direct Credit Grant Programs}

These programs are popular in many countries including in the industrialized countries like, the USA, Germany, Canada and Japan. Government initiated direct credit grant programs helped a lot in strengthening fledgling SMEs (OECD Report, 2001; American Recovery and Reinvestment Act of 2009). In the same way, GoB can launch and implement direct credit granting programs through its specialized agencies. As practiced in many countries, GoB can also delegate external organizations like banks and private and public organizations for this purpose. For example, GoB can grant direct subsidized loans to assist eligible SMEs located in rural and semi-urban as well as in economically and socially depressed areas. This helps to narrow disparities among different geographical areas in income, growth, migration and especially unemployment. To run these types of programs, mandated institutional capacities require details of eligibility criteria, loan administration procedures, repayment and security requirements and other loan related provisions. All these should be well formulated in advance. This and other initiatives discussed earlier are relevant and supportive, but they should be implemented in the best possible way.

\section{Financing of Technical and Managerial Advisory and Extension Services}

SMEs' problems are not only access to finance, but also proper utilization of funds at their disposal. Acquiring funds is only one part in the dynamic SMEs financing scenario. Equally important is developing the ability to appropriately utilize and prudently manage the acquired funds. The lack of capacity to obtain funds at the right time, of the right type, in the desired amount, and at various stages is also another important weakness usually observable in many SMEs. We should provide SMEs the desired support for technical and managerial extension services and capacity upgrading programs to develop these capabilities. This means that concerned governmental and parastatal institutional capacities should not only be limited to providing funds. Rather, they should support SMEs to attain the ability to utilize their available funds in a proper and innovative way. Such services may include co-sponsoring management training programs and workshops, providing training facilities (such as trainers, mentors and training kits) and informational materials, offering limited one-to-one counseling services to SMEs owners focusing on how to solve their business problems, providing technical, managerial and professional assistances.

Above all, effective implementation of schemes and focused action programs require possessing the capability to streamline, cluster, and properly manage SMEs' financing initiatives. In sum, government programs should not be limited to granting finance only. It is imperative that many SMEs in Botswana desperately need professional help focusing on how to use their funds effectively and efficiently. It is a good idea that government and other stakeholders grant financial assistance for providing technical and managerial extension services through capacity up grading and building programs. Such services may include:

- co-sponsoring management training programs, courses, conferences, seminars and workshops;

- providing trainers, speakers, panelists and moderators for training programs;

- providing training facilities, equipment and informational materials;

- offering limited one-to-one counseling services to SMEs' owners and managers;

- helping SMEs' owners/managers to identify and solve their business related problems;

- publicizing available free services to SMEs' owners at national, state and local levels; 
- helping to prepare and deliver management assistance through publications, radio, television and the print media (Adapted from SBA co-sponsorship programs, 1996).

Financing of technical and managerial training and advisory services' schemes can be concentrated around the so-called Software Economic Infrastructure Development Programs. The Software and Hardware Economic Infrastructures can be broken down into two categories as Figure 4 shows. Hence, government can participate in software economic promotional programs as a contribution to the achievement of specified objectives.

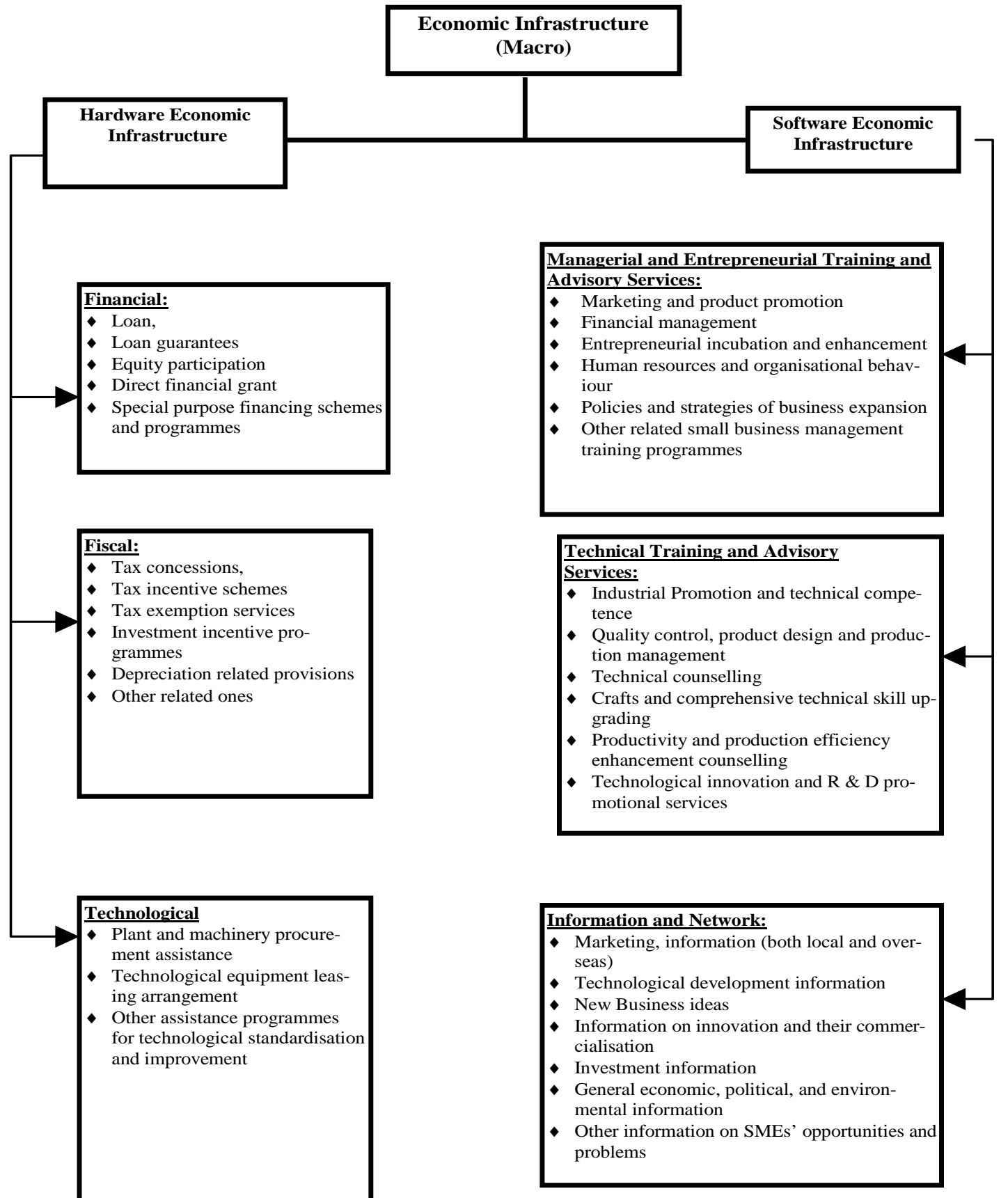

Figure 4. Vital economic infrastructures for SMEs' development. Source: Adapted from Owulah (1988), and re-formulated by the author. 


\section{Required Legal and Policy Underpinnings for the Promotion of SMEs Financing}

Lack of effective enforcement by a legal infrastructure opens the door for financial dualism. Financial dualism is detrimental for business and economic development. It gives room for manipulation and unproductive rent seeking activities that are harmful for the sustainable development of the national economy. The negative consequences of financial dualism have become a normal phenomenon in the majority of the developing countries of Africa, Asia and Latin America. The developed countries are not spared from this malaise. Todaro (2009) has rightly observed the harmful effect of the financial dualism particularly on the broad activities of SMEs in many developing countries. He said:

\footnotetext{
Most developing countries operate under a dual monetary system, a small and often externally controlled or influenced organized money market with severely binding legal restrictions on nominal interest rate ceilings, catering to the financial requirements of a special group of upper-class local and foreign businesses in the modern industrial sector, and a large but amorphous unorganized money market, uncontrolled, illegal, and often usurious to which most small and low income businesses are obliged to turn in times of financial need. (Todaro, 2009)
}

The above statement asserts that highly unorganized, often externally dependent, and spatially fragmented financial system greatly impedes the growth of the national economic infrastructures in general and those of SMEs in particular. Therefore, we need to establish a transparent and effective legal infrastructure to maintain an efficient financial system that fosters the growth of the national economy. This is indeed a major contributor to organized, economically interdependent, and functionally competent financial institutions, financial markets and financial instruments. As a result, prudently managed and leveraged financial resources can continuously flow in and out of savings banks, commercial banks, and other public and private financial intermediaries with a minimum interference. Thus, a fully functional financial system strengthened in such a mode can make a noticeable contribution to the alleviation of SMEs financing problems. One of the chief causes of the economic crises in African countries during the last 40 years is inept governance coupled with the adoption of conventional but largely irrelevant developmental policies and strategies directly copied from the developed countries (former colonial masters). Of course, Botswana has attempted to formulate and implement regulatory policies and legal underpinnings. However, the country should do more to advance, modernize and strengthen the institutional capacity of its financial sector to provide efficient services to the indigenous economic sectors including SMEs. The existence of judicious and workable legal and regulatory infrastructure can help SMEs to have better access to the financial resources available in the country. Figure 5 portrays the important position of the financial sector within the national economic system.

The author recommendations on the legal acts and regulatory policies for facilitating the financing intricacies of SMEs in particular are shown in Table 3. These recommended supporting legal and regulatory frameworks are intended to serve as a stepping-stone for more actions by the responsible government organs, principally the Bank of Botswana, Ministry of Commerce and Industry, Ministry of Finance, Office of the President, and institutions representing the private sector. 


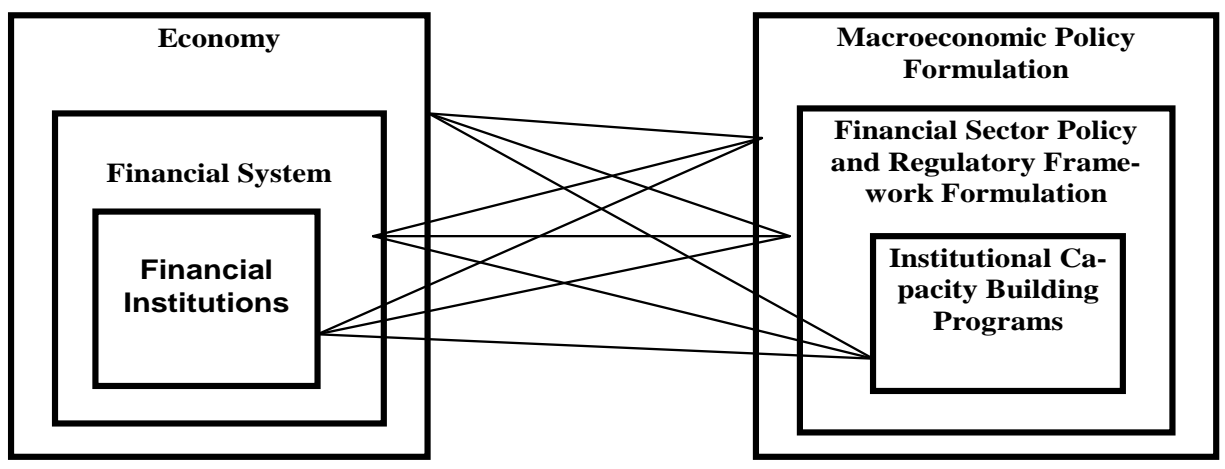

Figure 5. The complex of macroeconomic and sectoral relationships. Source: Adapted from Krahnen and Schmidt (1994) and re-formulated by the author.

Table 3

Proposed Legal Acts and Regulatory Policies Facilitating SMEs’ Financing

\begin{tabular}{|c|c|}
\hline Proposed act & Purpose (objective) \\
\hline $\begin{array}{l}\text { SMEs' Development } \\
\text { Establishment Act }\end{array}$ & $\begin{array}{l}\text { To establish an agency at a national level with the objective of promoting SMEs. This is to } \\
\text { stipulate the basic direction and policy of SMEs and accelerate their competitive growth. } \\
\text { Additionally, the proposed SMEs' development agency can establish different } \\
\text { departments (or affiliated units) including one directly dealing with SMEs financing. As } \\
\text { required, branch offices can also be established in different regions or localities of the } \\
\text { country. }\end{array}$ \\
\hline 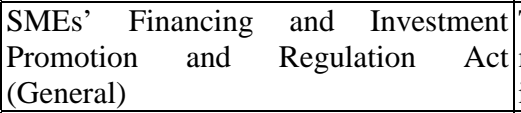 & $\begin{array}{l}\text { eedings regulating, supervising, and facilitating financing and } \\
\text { ecifically pertaining to SMEs. }\end{array}$ \\
\hline $\begin{array}{l}\text { SMEs’ Start-up Financial Support } \\
\text { Regulation and Supervision Act }\end{array}$ & $\begin{array}{l}\text { To provide for business venture start-up in order to contribute to the establishment of a } \\
\text { sound industrial structure by promoting the establishment of SMEs. The act may mainly } \\
\text { concentrate on issuance of regulations on how to grant financial support to SMEs for } \\
\text { start-up purposes. The proposed act can include special legal provisions to encourage the } \\
\text { establishment of SMEs in economically depressed regions. }\end{array}$ \\
\hline $\begin{array}{l}\text { Establishment, Licensing and } \\
\text { Supervision of the Micro-Financing } \\
\text { Institutions and Small Business } \\
\text { Investment Companies Act }\end{array}$ & $\begin{array}{l}\text { To encourage the increased flow of finance to SMEs in both rural and urban areas in the } \\
\text { form of loans, venture capital and/or equity investments and other means of financing. } \\
\text { This is vital for the accelerated and sustainable growth of SMEs and to bring the activities } \\
\text { of SMEs' and other micro-level financing institutions (mini-banks) within the monetary } \\
\text { and financial policies of the country. }\end{array}$ \\
\hline $\begin{array}{l}\text { SMEs' Credit Regulation and Control } \\
\text { Act }\end{array}$ & $\begin{array}{l}\text { As a supplementary to the above proposed SMEs' Financing Promotion Act, this } \\
\text { proposed act can be issued with the aim of regulating, supervising and controlling the } \\
\text { effectiveness of lending programs. Lending programs may be designed and implemented } \\
\text { by different formal lending institutions, mainly the commercial banks. This is with the } \\
\text { objective of ensuring that the special loan programs of banks and other financial } \\
\text { institutions targeting SMEs are effective and properly financed. }\end{array}$ \\
\hline SMEs Export Business Promotiona & $\begin{array}{l}\text { To provide the necessary legal and regulatory framework to assist SMEs engaged in } \\
\text { export business to get the necessary finance and to provide for other facilities, which can } \\
\text { help them to further promote their export business and enhance their competitiveness and } \\
\text { capacity. }\end{array}$ \\
\hline
\end{tabular}

\section{Concluding Remarks}

In this paper, the author raised the critical issues of SMEs financing as a pertinent issue. Like in other developing nations, Botswana SMEs have continued to suffer from the luck of access to finance due to multitude constraints. Some of them are discussed in this paper. The GoB is indeed in a better position to resourcefully engage in promoting SMEs. This is in line with its core development agenda. That was the main reason for the President of the country to appoint a Presidential Task Force to investigate and identify core problems hindering 
the development of SMEs in the country. The task force comprehensive report identified, among others, some core problems pertaining to SMEs financing. As part of the solution, the author proposed some government sponsored schemes, action programs and legal underpinnings. The author categorized them under four packages namely: direct financial assistance schemes; loan guarantee schemes; direct credit grant schemes; and financing of technical and managerial advisory services. The author is aware that SMEs' financing scenario is a formidable task that demands continued, joint efforts of all stakeholders. However, it is important to note that the primary goal is to stimulate SMEs to make efforts to meet their financing needs by strengthening their internal capabilities for attracting funds. Thus, we should expect SMEs to demonstrate their innovative endeavors by discovering viable sources of financing. While this is the main thrust of the broader efforts to secure support for SMEs, GoB has also a mandate to promoting SMEs including widening their access to finance at their different stages of developmental continuum. Various governments' sponsored financing schemes and action programs should be earmarked for this purpose. Realistically, SMEs in Botswana and in other SSA nations cannot solve their financing problem solely through their own efforts, particularly in the current globalized and turbulent business environment. Therefore, respective governments have an important role to play by assisting SMEs to enjoy substantial access to finance as a means for their sustained survival and growth. Government sponsored financing programs have been proved successful in many developed and developing nations. Therefore, government involvement in financing of SMEs can greatly contribute to alleviating financial problems of SMEs as a principal prerequisite for their active involvement in the dynamics of the national economy. It is also important to note that lending or granting money to SMEs is not enough, but government through its relevant institutional capacities should also assist SMEs to develop the ability of efficient utilization of the financial capacity at their disposal. If Botswana needs to achieve sustainable socio-economic growth through efficiency and economic diversification, empowerment of SMEs is fundamental. However, granted assistance should be in its appropriate form and content in order to bring qualitatively measured strength to SMEs that enhances their development and competitiveness. SMEs should note that government is not a panacea for all their problems. They should consider that government sponsored assistance programs are limited in scope and outreach and cannot solve their financing problems entirely. They should deal with their financing problems in accordance with the dynamics of the conventional economic rationality. They should boldly confront the challenge and work harder to enhance their strength and marginalize their weaknesses within the dynamics of organizational competency and growth. They should always find themselves in a continuous improvement endeavors and thereby foster their competitiveness in attracting external finance in the smartest way. The productive alliance of government, SMEs, and financial institutions can be quite supportive for SMEs empowerment. Indeed well integrated, supported and synchronized SMEs will be more capable to lead the socio-economic development continuum in Botswana.

\section{References}

Analytics, G. (2003). Access to financial services in Botswana. Johannesburg: FinMark Trust research paper 1, FinMark Publication Anand, G., \& Chandavarkar, K. (1998). Informal credit market in support of micr-obusiness. A paper presented in the International Conference on Microenterprise Development, Washington D.C., I.T. Publication in London, May.

Anderson, D., \& Khambata, F. (1982). Financing small-scale industries and agriculture in developing countries: The merits and limitations of commercial policies (pp. 913-948). Washington: Third World Bank Staff working papers No. 519.

Aredo, D. (1993). The Eqqub and its potential as an indigenous institution financing small enterprises in Ethiopia. In A. H. J. Helmsing, \& T. Klostee (Eds.), Small enterprises and changing policies. London: Intermediate Technology Publications. 
Aryeetey, E. (1993). Sectoral credit allocation policy and credit flow to small enterprises in Ghana. In A. H. J. Helmsing, \& T. Klostee (Eds.), Small enterprises and changing policies. London: Intermediate Technology Publications.

Atkin, et al. (Eds.). (1993). New directions in small business research. Aldershot: Avebury.

Bates, J., \& Hally, D. L. (1982). The financing of small business (3rd ed.). London: Sweet and Maxwell Pub.

Brigham, E. F. (1983). Fundamentals of financial management. Chicago: Dryden Press.

Brigham, E. F., \& Houston, J. F. (1998). Fundamentals of financial management. Chicago: Dryden Press.

Briscoe, A. (1995).. Small business support in Botswana. Gaborone: Morula Press.

Central Statistical Office. (2000/2001). Botswana statistical report for 2000/2001. Gaborone: Government Publishing Services.

Chase, et al. (1983). Small business financing-federal assistance and contracts. Colorado Springs: McGraw-Hill Inc..

Chunyun, F. (2003). Government support for small and medium-sized enterprises in China. Problems of Economic Transition, 45(11).

Cook, P. (2001). Finance and small and medium-sized enterprise in developing countries. Journal of Developmental Entrepreneurship, 6(1), 17, 24.

Curry, Jr., \& Robert, L. (1987). Botswana's macroeconomic management of its mineral based growth. American Journal of Economics and Sociology, 46(4).

Daniels, L., \& Fisseha, Y. (1992). Micro and small-scale enterprises in Botswana, Maryland. Gemini Technical Report No. 46, Development Alternatives Inc.

Deutsche Ausgleich Bank (DtA). (1996). Finanzierungsbausteine für Unternehmen mit Zukunft. Bonn: DtA Publikation.

Duncombe, R., \& Heeks, R. (2001). Information technologies and small enterprises in Africa: Lessons from Botswana. Manchester: IDPM, University of Manchester.

Enterprise Promotion Agency. (1999). National small business regulatory review. Johannesburg, South Africa.

Government of Botswana. (1996). Vision 2016, prosperity for all. Gaborone: Government Press.

Government of Botswana. (1998a) National development plan 8. Gaborone: Government Press.

Government of Botswana. (1998b). Small, medium and micro enterprises task force report. Gaborone: Government Press.

Government of Botswana. (1999). National Policy on SMEs in Botswana (Government White Paper No. 1). Gaborone: Government Press.

Government of Botswana. (2008). Botswana Statistical Report, 2007/2008. Gaborone: Government Press.

Harrison, Richard and Mason, Colin. (Eds.). (1996). Informal venture capital. London: Prentice-hall Inc..

Hatten, T. S. (1997). Small Business: Entrepreneurship and beyond. New Jersey: Prentice Hall Inc..

Henderson, J. W. (1988). Obtaining venture financing - A guide for entrepreneurs. Toronto: DC Heath and Co..

Hinton, et al. (2006). Botswana small and medium enterprise under-banked market research. Johannesburg: Enterprises Banking Group Publications.

Hull, C. (1983). Federal republic of Germany. In D. J. Storey (Ed.), The small firm. London: An International Survey, Croom Helm.

Krahnen, P., \& Schmidt, R. (1994). Development finance as institutions' building—A new approach to poverty oriented banking. Boulder: Westview Press.

Kuratko, Do. F., \& Hodgetts, R. M. (2007). Entrepreneurship—Theory, process, and practice (6th ed.). Ohio: Thomson South-western, US.

Levitsky, J. (1989). Micro-enterprises in developing countries. London: Intermediate Technology Publication.

Liedholm, C., \& Fuzzy, H. (1994). Small enterprise employment growth in rural Africa. American Journal of Agricultural Economics, 76(5).

Liedholm, C. (1992). Small-scale enterprise dynamics and the evolving role of informal finance. In D. Adams, \& D. Fitchett (Eds.), Informal finance in low-income countries (pp. 265-280). Boulder: West View Press.

Liedholm, C. (1993). Small and micro-enterprise dynamics and the evolving role of finance. In A. H. J. Helmsing, \& T. Klostee (Eds.), Small enterprises and changing policies. London: Intermediate Technology Publications.

Lisenda, L. (1997). Small and medium-scale enterprises in Botswana: Their characteristics, sources of finance and problems. Gaborone: Botswana Institute for Development Policy Analysis (BIDPA) working paper No. 14.

McCormick, D. (1999). African enterprise clusters and industrialization: Theory and reality. World Development, 27(9), 1531-1552.

McGrath, S. A., \& King, K. (1999). Enterprise in Africa: Between poverty and growth. London: Intermediate Technology.

McPherson, M. A. (1996). Growth of micro and small enterprises in Southern Africa. Journal of Development Economics, 48(2), 253-278 
Morewagae, B. S., Monica, S., \& Henry, R. (1995). Access to credit for non-formal micro-enterprises in Botswana. Journal of Development Studies, 3(3).

Mwarania, K. M. (1993). financing small-scale and microenterprises in Kenya under conditions of liberalized financial markets. In A. H. J. Helmsing, \& T. Klostee (Eds.), Small enterprises and changing policies. London: Intermediate Technology Publications.

OECD. (1995). Best practices and policies for small and medium-sized enterprises. Paris: OECD Publications.

OECD. (2001). Entrepreneurship, growth and policy. Paris: OECD Publications.

Owualah, S. I. (1988). Providing the necessary economic infrastructure for small businesses: Whose responsibility? International Small Business Journal, 7(1), 10-30.

Oyejide, A. T. (1993). Financial liberalization under structural adjustment and its implications for financing small-scale and microenterprises in Nigeria. In A. H. J. Helmsing, \& T. Klostee (Eds.), Small enterprises and changing policies. London: Intermediate Technology Publications.

Patrice, D. (1993). Entwicklungsstrategien fur die Drittewelt (M. V. Hauff, \& W. Heinecke, Eds.). Berlin: Verlag der Wissenshaft and Praxis.

Rempel, et al. (1994). The place of non-formal micro enterprises in Botswana. Gaborone: University of Botswana Publications.

Roux, V. (1999). Integrated entrepreneurship development in the SME sector of the South African economy (Unpublished MBA Thesis, University of Stellenbosch).

Schoombee, A. (2000). Getting South African banks to serve micro-entrepreneurs: An analysis of policy options. Development Southern Africa, 17(5).

Small Business Administration (SBA). (1996). Co-sponsorship program. Washington: SBA Publications.

Steel, W. F., \& Webster, L. M. (1991). Small enterprises under adjustment in Ghana. Washington: World Bank technical paper, No. 139, Industry and Finance Series.

Sunny, G. (2000). Structural change, employment and small business-lessons of experience from Botswana. Gaborone: Tasalls Publisher.

Tesfayohannes, M. (1998). The promotion of small and medium-scale enterprises financing as a contribution to sustainable industrial development-The case of Eritrea. Aachen: Shaker Verlag, Germany.

The European Network for SMEs Research. (1993). The European observatory for SMEs, First Annual Report. Brussels, ENSR Publications.

The European Network for SMEs Research. (1995). The European observatory for SMEs, Third Annual Report. Brussels, ENSR Publications.

Todaro, M. P., \& Smith, S. C. (2009). Economic development (10th ed.). New York: Addison-Wesley.

USA Federal Government. (2009). American recovery and reinvestment act of 2009. Washington: Federal Government Publications.

van Dijk, M. P., \& Sandee, H. (2002). Innovation and small enterprises in the third world. Cheltenham: Edward Elgar.

Walker, E. W., \& Petty, W. J. (1986). Financial management of the small firm (2nd ed.). New Jersey: Prentice-hall Inc.. 